\title{
Effects of leaf and berry extracts of Phytolacca dioica L. on haematological and weight parameters of Wistar rats
}

\author{
A. O. T. Ashafa ${ }^{1 \star}$, T. O. Sunmonu ${ }^{2}$ and A. J. Afolayan ${ }^{3}$ \\ ${ }^{1}$ Department of plant sciences, University of the Free State, Qwaqwa Campus, Phuthaditjhaba, South Africa. \\ ${ }^{2}$ Department of Biochemistry, University of Ilorin, Ilorin, Nigeria. \\ ${ }^{3}$ Department of Botany, University of Fort Hare, Alice 5700, Eastern Cape, South Africa.
}

Accepted 25 January, 2011

\begin{abstract}
The effect of aqueous leaf and berry extracts of Phytolacca dioica administered at 50, 100 and 200 $\mathrm{mg} / \mathrm{kg}$ body weight for 14 days was investigated on haematology and weight parameters of Wistar rats. The extracts at all doses had no significant effect on the red blood cells (RBC), haemoglobin (HB), parked cell volume (PCV), mean corpuscular volume (MCV), mean corpuscular haemoglobin (MCH) and mean corpuscular haemoglobin concentration (MCHC) when compared with the animals in the control group. In contrast, the extracts at all doses caused a progressive significant reduction in the serum levels of platelets, white blood cells (WBC), neutrophils and monocytes. Also, there was dosedependent significant increase in the serum levels of lymphocytes and a reduction in the level of eosinophils. Administration of the extracts at all doses investigated led to a significant reduction in the body weight, absolute organ weight and organ-body weight ratio. These observable alterations in some parameters were indications that the leaf and berry extracts of $\boldsymbol{P}$. dioica possess slight toxicity. Therefore, the crude extracts from the leaf and berry may not be completely safe as oral remedies.
\end{abstract}

Key words: Phytolacca dioica, haematology, weight parameters, slight toxicity, oral remedy.

\section{INTRODUCTION}

The use of plants in medicine is not limited or restricted to any region of the world. It is an age-long practice in various parts of the globe for both preventive and curative purposes. Dependence on herbs as medicine in the treatment of diseases is still much practiced by a large proportion of the rural populace because of its ready availability and affordability (Sani et al., 2009). The long history of clinical application and natural origin guarantee that herbal products are effective and non-toxic (Shin et al., 2009).

Recently, concerns have been raised over the lack of quality control and scientific evidence for the efficacy and safety of medicinal plants (Firenzuoli and Gori, 2007; Rousseaux and Schachter, 2003). Several warnings have been issued regarding the potential adverse effects of herbal remedies including hepatotoxicity and nephrotoxicity (Wojcikowski et al., 2004; Stickel et al., 2005;

${ }^{*}$ Corresponding author. E-mail: tom.ashafa@gmail.com. Tel: +27766757599 .
Seeff, 2007; Tang et al., 2008). Medicinal plants typically contain several different pharmacologically active compounds that may act individually, additively or in synergy to improve health (Azaizeh et al., 2003; Gurib-Fakim, 2006). Bitters for example, are known to stimulate digestion while phenolic compounds could be responsible for anti-inflammatory and anti-oxidative activity of plant extracts. There is continuing interest in the evaluation of natural products as potential chemotherapeutic agents. This is encouraged by isolation of phytochemicals in plants which could become important drugs in modern medicine (Wintola et al., 2010). Plants produce bioactive compounds which act as defense mechanisms against predators and at the same time, may be toxic in nature (Da Roch et al., 2001; Bent and Ko, 2004). With the upsurge of interests in medicinal plants, there is need for thorough scientific investigations of these plants for both efficacy and potential toxicity (Ashafa et al., 2010).

One such plant is Phytolacca dioica Linn (Phytolaccaceae), which was introduced into South Africa from its native South America (Van Wyk et al., 2002). It is a tree otherwise known as Belhambra (English) or 
'Belhambraboom' ('Afrikaans') and can easily be recognized by its massive trunk, simple and somewhat fleshy leaves borne on pinkish petioles with a pendulous cluster of berries (Van Wyk et al., 2002). The leaves and berries of $P$. dioica have been reported to be rich sources of triterpenoid saponins, which have been described as displaying important biological activities such as molluscicidal, anti-inflammatory, antifungal and antibacterial effects (Blanco et al., 1998). Ethnopharmacological information also revealed that $P$. dioica is used for healing skin wounds (Quiroga et al., 2001). Also, a number of ribosome inactivating proteins (RIPs) that are potentially useful for the development of immunotoxins for tumor therapy and the production of transgenic plants endowed with specific parasite resistance have been isolated from the plant (Brinkmann et al., 1991; Blanco et al., 1997, 1998).

Recent ethnobotanical information indicated that aqueous extracts of $P$. dioica leaf and berry are taken orally for the treatment of microbial infections in some communities of South Africa. Previous report also revealed that the extracts significantly increased the serum activities of alkaline phosphatase, $Y$ glutamyltransferase, alanine transaminase and aspartate transaminase after 14 days continuous administration in experimental animals (Ashafa et al., 2010). Considering these developments coupled with the potential health benefits of this plant as reported in scientific literature, it becomes imperative to provide more information on the safety/toxicity of $P$. dioica extracts. Hence, the present study was carried out to evaluate the effects of aqueous leaf and berry extracts of $P$. dioica on the haematology and weight parameters of Wistar rats.

\section{MATERIALS AND METHODS}

\section{Plant collection and extract preparation}

The berries and leaves of $P$. dioica were collected in August 2009 from a single tree growing on the Alice Campus of the University of Fort Hare in the Eastern Cape Province of South Africa. The plant materials were authenticated by Prof. D. S. Grierson of the Botany Department and a voucher specimen (Ashmed 09/04) was prepared and deposited in the University herbarium.

The leaves and berries were dried in the oven at $40^{\circ} \mathrm{C}$ to a constant weight and the two samples were separately pulverized into fine powder. The dried materials (25 g each) were extracted separately in distilled water for $24 \mathrm{~h}$ on orbital shaker (Stuart Scientific Orbital Shaker, UK) and filtered using a Buckner funnel and Watman No. 1 filter paper. The filterate was freeze-dried (Vir Tis benchtop K Series, USA) to give yields of 4.08 and $6.72 \mathrm{~g}$ for leaf and berry respectively which were reconstituted separately in distilled water to give the required doses of 50,100 and $200 \mathrm{mg} / \mathrm{kg}$ body weight for the experiment.

\section{Animals used}

Male albino rats of Wistar strain with a mean weight of $150.48 \pm$ $2.46 \mathrm{~g}$ were obtained from the Experimental Animal House of the Agricultural and Rural Development Research Institute (ARDRI),
University of Fort Hare, Alice, South Africa. The animals were housed in clean metabolic cages placed in a well ventilated house with optimum condition (temperature: $23 \pm 1{ }^{\circ} \mathrm{C}$; photoperiod: $12 \mathrm{~h}$ natural light and $12 \mathrm{~h}$ dark; humidity: 45 to $50 \%$ ). They were acclimatized to animal house conditions and allowed free access to commercial pelleted rat chow (Pioneer Foods (Pty) Ltd., Huguenot, South Africa) and water. The cleaning of the cages was done on a daily basis. This study was carried out following approval from the Ethical Committee on the use and care of animals of the University of Fort Hare, South Africa.

\section{Animal grouping and extract administration}

Forty-two male rats were randomized into seven groups of six animals each. Group 1 (control) were orally administered with distilled water. Groups 2 to 4 were orally treated with 50, 100 and 200 $\mathrm{mg} / \mathrm{kg}$ body weight/day of $P$. dioica berry extract while groups 5 to 7 received the same dosages of $P$. dioica leaf extract respectively. The treatment continued for 14 days and the administration was done using metal oropharyngeal cannula.

\section{Collection of blood sample and isolation of organs}

After 14 days of extract administration, the rats were humanely sacrificed by ether anaesthetization and the neck area was quickly cleared of fur to expose the jugular vein. The vein, after being slightly displaced, was sharply cut with sterile surgical blade and an aliquot $(5 \mathrm{ml})$ of the blood was collected into sample bottles containing EDTA (BD Diagnostics, preanalytical systems, Midrand, USA) for haematological analysis. The rats were quickly dissected and the whole liver and two kidneys were excised, freed of fat, blotted with clean tissue paper and then weighed. The organ to body weight ratio was determined by comparing the weight of each organ with the final body weight of each rat.

\section{Determination of haematological parameters}

Using Horiba ABX 80 Diagnostics (ABX Pentra Montpellier, France), the following analyses were carried out: Red blood count $(\mathrm{RBC})$, haemoglobin (HGB), packed cell volume (PCV), mean corpuscular volume (MCV), mean corpuscular haemoglobin $(\mathrm{MCH})$, mean corpuscular haemoglobin concentration $(\mathrm{MCHC})$, platelet (PLT), white blood cells (WBC) and white blood cell differential counts.

\section{Statistical analysis}

Data were expressed as mean \pm SD of six replicates and were subjected to one way analysis of variance (ANOVA) followed by Duncan multiple range test to determine significant differences in all the parameters. Values were considered statistically significant at $p$ $<0.05$.

\section{RESULTS}

The administration of the aqueous extracts from the leaf and berry of $P$. dioica at 50,100 and $200 \mathrm{mg} / \mathrm{kg}$ body weight caused a reduction in the overall body weight, absolute organ weight and organ-body ratio of experimental animals (Tables 1 and 2). The extracts had no significant effect on RBC, HGB, PCV, MCV, MCH and 
Table 1. Effect of aqueous leaf extract of $P$. dioica $L$. on weight parameters of Wistar rats $(n=6, X \pm S D)$.

\begin{tabular}{|c|c|c|c|c|}
\hline Parameter & Control & $50 \mathrm{mg} / \mathrm{kg}$ & $100 \mathrm{mg} / \mathrm{kg}$ & $200 \mathrm{mg} / \mathrm{kg}$ \\
\hline Initial body weight (g) & $150.37 \pm 4.48^{\mathrm{a}}$ & $150.07 \pm 4.74^{\mathrm{a}}$ & $150.50 \pm 4.13^{a}$ & $150.93 \pm 4.25^{\mathrm{a}}$ \\
\hline Final body weight $(\mathrm{g})$ & $176.43 \pm 1.05^{\mathrm{a}}$ & $165.35 \pm 1.64^{b}$ & $160.77 \pm 1.70^{\mathrm{C}}$ & $159.27 \pm 2.25^{\mathrm{c}}$ \\
\hline Liver weight $(\mathrm{g})$ & $4.89 \pm 0.15^{\mathrm{a}}$ & $4.23 \pm 0.12^{b}$ & $3.82 \pm 0.06^{c}$ & $3.40 \pm 0.09^{d}$ \\
\hline Kidney weight (g) & $1.07 \pm 0.05^{\mathrm{a}}$ & $0.80 \pm 0.04^{b}$ & $0.64 \pm 0.02^{d}$ & $0.53 \pm 0.02^{\mathrm{e}}$ \\
\hline Liver-body weight (g) & $2.77 \pm 0.03^{\mathrm{a}}$ & $2.56 \pm 0.02^{b}$ & $2.38 \pm 0.03^{d}$ & $2.15 \pm 0.02^{\mathrm{e}}$ \\
\hline Kidney-body weight $(\mathrm{g})$ & $0.61 \pm 0.02^{\mathrm{a}}$ & $0.48 \pm 0.03^{\mathrm{c}}$ & $0.39 \pm 0.01^{d}$ & $0.33 \pm 0.01^{\mathrm{e}}$ \\
\hline
\end{tabular}

Means with the same superscript across the row for each parameter are not significantly different $(p<0.05)$.

Table 2. Effect of aqueous berry extract of $P$. dioica $L$. on weight parameters of Wistar rats $(n=6, X \pm S D)$.

\begin{tabular}{|c|c|c|c|c|}
\hline Parameter & Control & $50 \mathrm{mg} / \mathrm{kg}$ & $100 \mathrm{mg} / \mathrm{kg}$ & $200 \mathrm{mg} / \mathrm{kg}$ \\
\hline Initial body weight (g) & $150.37 \pm 4.48^{a}$ & $150.60 \pm 4.84^{\mathrm{a}}$ & $150.33 \pm 4.96^{\mathrm{a}}$ & $150.83 \pm 4.80^{\mathrm{a}}$ \\
\hline Final body weight (g) & $176.43 \pm 1.05^{\mathrm{a}}$ & $168.77 \pm 1.16^{b}$ & $162.93 \pm 1.06^{\mathrm{C}}$ & $160.43 \pm 1.19^{c}$ \\
\hline Liver weight $(\mathrm{g})$ & $4.89 \pm 0.15^{\mathrm{a}}$ & $4.30 \pm 0.09^{b}$ & $3.96 \pm 0.10^{c}$ & $3.72 \pm 0.18^{c}$ \\
\hline Kidney weight (g) & $1.07 \pm 0.05^{\mathrm{a}}$ & $0.87 \pm 0.05^{b}$ & $0.74 \pm 0.02^{\mathrm{C}}$ & $0.72 \pm 0.02^{\mathrm{c}}$ \\
\hline Liver-body weight (g) & $2.77 \pm 0.03^{\mathrm{a}}$ & $2.55 \pm 0.02^{b}$ & $2.43 \pm 0.02^{c}$ & $2.32 \pm 0.02^{d}$ \\
\hline Kidney-bodyweight (g) & $0.61 \pm 0.02^{\mathrm{a}}$ & $0.52 \pm 0.01^{b}$ & $0.45 \pm 0.01^{\mathrm{c}}$ & $0.45 \pm 0.01^{\mathrm{c}}$ \\
\hline
\end{tabular}

Means with the same superscript across the row for each parameter are not significantly different $(p<0.05)$.

MCHC. In contrast however, the extracts caused significant reduction in platelets, WBC, neutrophils and monocytes. Whereas there was a dose dependent significant increase in the level of serum lymphocytes, a dose dependent decrease was observed in the level of serum eosinophil (Tables 3 and 4).

\section{DISCUSSION}

The administration of herbal preparations without any standard dosage coupled with non- availability of adequate scientific studies on their safety has raised concerns on their toxicity (Saad et al., 2006). Alteration in weight is an indication of impairment in the normal functioning of the organs. Organ-body weight ratio may indicate organ swelling, atrophy or hypertrophy (Amresh et al., 2008). The reduction in the liver- and kidney-body weight ratios following the administration of aqueous extract of $P$. dioica may be attributed to atrophy. This submission is supported by the observed reduction in the body and absolute organ weights of the animals.

Assessment of haematological parameters can be used to determine the extent of deleterious effect of foreign compounds including plant extracts on the blood constituents of an animal (Ashafa et al., 2009). It can also be used to explain blood relating functions of chemical compounds/plant extract (Yakubu et al., 2007). The various haematological parameters investigated in this study are useful indices that can be employed to assess the toxic potentials of plant extracts/botanicals in living systems (Sunmonu and Oloyede, 2010). Such toxicity testing is relevant to risk evaluation as changes in the haematological system have higher predictive value for human toxicity, when data are translated from animal studies (Olson et al., 2000).

The non significant effect of the extracts on RBC could mean that the balance between the rate of production and destruction of blood corpuscles (erythropoiesis) was not affected negatively. $\mathrm{MCH}, \mathrm{MCHC}$ and $\mathrm{MCV}$ relates to individual red blood cells while $\mathrm{Hb}, \mathrm{RBC}$ and PCV are associated with the total population of red blood cells. Therefore, the absence of observable significant effect of the extracts on these parameters may be an indication that neither the incorporation of haemoglobin into the red blood cells nor the morphology and osmotic fragility of the red blood cells was altered (Adebayo et al., 2005).

The reduction in platelets, WBC, neutrophils and monocytes observed in this study suggests selective and localized toxicity. Reduction in platelets count in experimental animals has been reported to indicate adverse effect on the oxygen-carrying capacity of the blood as well as thrombopoietin (Li et al., 1999; McLellan et al., 2003). Lymphocytes are the main effector cells of the immune system (Yakubu et al., 2007; Ashafa et al., 2009). Therefore, the observed increase in the level of lymphocytes in our study may suggest stimulation of the immune system of the animals. Monocytes have been shown to increase in cases of infection; hence the reduction in monocytes could imply that there was little or no infection caused by the extract.

In conclusion, the alterations in weight and certain 
Table 3. Effect of aqueous leaf extract of $P$. dioica $L$. on the haematological parameters of Wistar rats $(n=6, X \pm S D)$.

\begin{tabular}{lcccc}
\hline Parameter & Control & $\mathbf{5 0 ~} \mathbf{~ g / k g}$ & $\mathbf{1 0 0} \mathbf{~} \mathbf{g} / \mathbf{k g}$ & $\mathbf{2 0 0} \mathbf{~} \mathbf{g} / \mathbf{k g}$ \\
\hline RBC $\left(\times 10^{12} / \mathrm{L}\right)$ & $7.78 \pm 0.58^{\mathrm{a}}$ & $8.42 \pm 0.78^{\mathrm{a}}$ & $8.00 \pm 0.35^{\mathrm{a}}$ & $7.83 \pm 0.53^{\mathrm{a}}$ \\
HGB (g/L) & $13.88 \pm 0.84^{\mathrm{a}}$ & $15.17 \pm 1.40^{\mathrm{a}}$ & $14.80 \pm 1.00^{\mathrm{a}}$ & $14.53 \mathrm{v}^{\mathrm{a}} .94^{\mathrm{a}}$ \\
PCV (L/L) & $0.46 \pm 0.01^{\mathrm{a}}$ & $0.49 \pm 0.02^{\mathrm{a}}$ & $0.49 \pm 0.02^{\mathrm{a}}$ & $0.48 \pm 0.02^{\mathrm{a}}$ \\
MCV (fl) & $59.30 \vee 1.94^{\mathrm{a}}$ & $58.97 \pm 1.99^{\mathrm{a}}$ & $61.57 \pm 1.33^{\mathrm{a}}$ & $61.93 \pm 1.43^{\mathrm{a}}$ \\
MCH (pg) & $17.83 \pm 1.40^{\mathrm{a}}$ & $18.03 \pm 0.54^{\mathrm{a}}$ & $18.47 \pm 0.73^{\mathrm{a}}$ & $18.60 \pm 0.94^{\mathrm{a}}$ \\
MCHC $(\%)$ & $30.10 \pm 0.40^{\mathrm{a}}$ & $30.53 \pm 0.61^{\mathrm{a}}$ & $30.00 \pm 0.33^{\mathrm{a}}$ & $30.03 \pm 0.34^{\mathrm{a}}$ \\
PLTS $\left(\times 10^{9} / \mathrm{L}\right)$ & $845.67 \pm 12.94^{\mathrm{a}}$ & $738.00 \pm 11.99^{\mathrm{b}}$ & $691.33 \pm 10.33^{\mathrm{c}}$ & $684.67 \pm 11.43^{\mathrm{c}}$ \\
WBC $\left(\times 10^{9} / \mathrm{L}\right)$ & $13.83 \pm 0.95^{\mathrm{a}}$ & $7.72 \pm 1.04^{\mathrm{b}}$ & $8.36 \pm 1.00^{\mathrm{b}}$ & $8.98 \pm 1.08^{\mathrm{b}}$ \\
NEUT $\left(\times 10^{9} / \mathrm{L}\right)$ & $10.50 \pm 0.50^{\mathrm{a}}$ & $6.83 \pm 0.24^{\mathrm{d}}$ & $6.67 \pm 0.10^{\mathrm{d}}$ & $5.77 \pm 0.38^{\mathrm{c}}$ \\
MONO $\left(\times 10^{9} / \mathrm{L}\right)$ & $25.53 \pm 0.71^{\mathrm{a}}$ & $22.56 \vee 0.14^{\mathrm{d}}$ & $17.73 \pm 0.21^{\mathrm{b}}$ & $17.70 \pm 0.18^{\mathrm{b}}$ \\
LYMP $\left(\times 10^{9} / \mathrm{L}\right)$ & $50.10 \pm 1.67^{\mathrm{a}}$ & $57.00 \vee 1.16^{\mathrm{c}}$ & $61.61 \pm 2.16^{\mathrm{b}}$ & $63.47 \pm 1.49^{\mathrm{b}}$ \\
EOSINO $\left(\times 10^{9} / \mathrm{L}\right)$ & $2.93 \pm 0.12^{\mathrm{a}}$ & $2.53 \pm 0.16^{\mathrm{b}}$ & $2.43 \pm 0.11^{\mathrm{b}}$ & $1.53 \pm 0.31^{\mathrm{c}}$ \\
\hline
\end{tabular}

Means with the same superscript across the row for each parameter are not significantly different $(p<0.05)$.

Table 4. Effects of aqueous berry extract of $P$. dioica $L$. on the haematology parameters of Wiatar rats $(n=6, X \pm S D)$.

\begin{tabular}{|c|c|c|c|c|}
\hline Parameter & Control & $50 \mathrm{mg} / \mathrm{kg}$ & $100 \mathrm{mg} / \mathrm{kg}$ & $200 \mathrm{mg} / \mathrm{kg}$ \\
\hline $\operatorname{RBC}\left(\times 10^{12} / \mathrm{L}\right)$ & $7.78 \pm 0.58^{a}$ & $7.22 \pm 0.95^{\mathrm{a}}$ & $7.79 \pm 0.69^{a}$ & $8.12 \pm 0.83^{a}$ \\
\hline HGB (g/L) & $13.88 \pm 0.84^{\mathrm{a}}$ & $13.65 \pm 0.25^{\mathrm{a}}$ & $14.47 \pm 0.87^{\mathrm{a}}$ & $14.70 \pm 0.93^{\mathrm{a}}$ \\
\hline PCV (L/L) & $0.46 \pm 0.01^{\mathrm{a}}$ & $0.46 \pm 0.01^{\mathrm{a}}$ & $0.48 \pm 0.02^{\mathrm{a}}$ & $0.49 \pm 0.02^{\mathrm{a}}$ \\
\hline MCV (fl) & $59.30 \pm 1.94^{\mathrm{a}}$ & $68.25 \pm 1.01^{\mathrm{a}}$ & $61.40 \pm 1.29^{\mathrm{a}}$ & $60.73 \pm 1.98^{\mathrm{a}}$ \\
\hline $\mathrm{MCH}(\mathrm{pg})$ & $17.83 \pm 1.40^{\mathrm{a}}$ & $18.95 \pm 0.95^{\mathrm{a}}$ & $18.50 \pm 0.97^{\mathrm{a}}$ & $18.10 \pm 0.67^{a}$ \\
\hline $\mathrm{MCHC}(\%)$ & $30.10 \pm 0.40^{\mathrm{a}}$ & $29.95 \pm 0.65^{\mathrm{a}}$ & $30.20 \pm 0.35^{\mathrm{a}}$ & $29.83 \pm 0.67^{\mathrm{a}}$ \\
\hline PLTS $\left(\times 10^{9} / \mathrm{L}\right)$ & $845.67 \pm 12.94^{a}$ & $763.67 \pm 14.01^{b}$ & $756.33 \pm 15.29^{b}$ & $742.00 \pm 13.98^{b}$ \\
\hline WBC $\left(\times 10^{9} / \mathrm{L}\right)$ & $13.83 \pm 0.95^{\mathrm{a}}$ & $6.43 \pm 1.40^{\mathrm{b}}$ & $6.64 \pm 1.25^{\mathrm{b}}$ & $7.47 \pm 1.07^{\mathrm{b}}$ \\
\hline NEUT $\left(\times 10^{9} / L\right)$ & $10.50 \pm 0.50^{\mathrm{a}}$ & $8.10 \pm 0.49^{b}$ & $5.80 \pm 0.52^{\mathrm{C}}$ & $5.70 \pm 0.57^{c}$ \\
\hline MONO $\left(\times 10^{9} / L\right)$ & $25.53 \pm 0.71^{\mathrm{a}}$ & $19.50 \pm 0.39^{b}$ & $18.40 \pm 0.64^{b}$ & $14.67 \pm 0.24^{c}$ \\
\hline LYMP $\left(\times 10^{9} / \mathrm{L}\right)$ & $50.10 \pm 1.67^{\mathrm{a}}$ & $62.70 \pm 1.01^{b}$ & $63.27 \pm 1.21^{\mathrm{b}}$ & $63.70 \pm 1.94^{b}$ \\
\hline EOSINO $\left(\times 10^{9} / \mathrm{L}\right)$ & $2.93 \pm 0.12^{\mathrm{a}}$ & $2.47 \pm 1.10^{\mathrm{b}}$ & $2.20 \pm 0.21^{\mathrm{b}}$ & $1.15 \pm 0.49^{c}$ \\
\hline
\end{tabular}

Means with the same superscript across the row for each parameter are not significantly different $(p<0.05)$.

haematological parameters observed in the present study point to selective toxicity of $P$. dioica extracts on the immune system of experimental animals. Therefore, the herb may not be completely safe as an oral remedy at the doses investigated.

\section{ACKNOWLEDGEMENT}

We acknowledge the National Research Foundation of South Africa, Govan Mbeki Research and Development Centre of the University of Fort Hare and the Department of Biochemistry, University of Ilorin, Nigeria for the release of Dr. TO Sunmonu for post-doctoral fellowship.

\section{REFERENCES}

Adebayo JO, Adesokan AA, Olatunji LA, Buoro DO, Soladoye AO (2005). Effect of Ethanolic extract of Bougainvillea spectabilis leaves on haematological and serum lipid variables in rats. Biokem, 17: 45-50. Amresh GR, Singh PN, Rao VC (2008). Toxicological screening of traditional medicine Laghupatha (Cissampelos pareira) in experimental animals. J. Ethnopharmacol., 116: 454-460.

Ashafa AOT, Yakubu MT, Grierson DS, Afolayan AJ (2009). Effects of aqueous leaf extract from the leaves of Chrysocoma ciliate L. on some biochemical parameters of Wistar rats. Afr. J. Biotechnol., 8: $1425-1430$

Ashafa AOT, Sunmonu TO, AJ Afolayan (2010). Toxicological evaluation of aqueous leaf and berry extracts of Phytolacca dioica L. in male Wistar rats. Food Chem. Toxicol., 48: 1886-1889.

Azaizeh H, Fulder S, Khalil K, Said O (2003): Ethnobotanical knowledge of local Arab practitioners in the Middle Eastern region. Fitoter. 74: 98-108.

Bent S, Ko R (2004). Commonly used herbal medicines in the United States: a review. Am. J. Med., 116: 478-485.

Blanco FDV, Bolognesi A, Malorni A, Sande MJW, Savino G, Parente A (1997). Complete amino acid sequence of PD-S2, a new ribosomeinactivating protein from seeds of Phytolacca dioica L. Biochim. Biophys. Acta, 1338: 137-144.

Blanco FDV, Cafaro V, Di Maro A, Scognamiglio R, Siniscalco G, Parente A, Di Donato A (1998). A recombinant ribosome-inactivating protein from the plant Phytolacca dioica L. produced from a synthetic 
gene. FEBS Lett., 437: 241-245.

Brinkmann U, Pai LH, FitzGerald DJ, Willingham M, Pastan I (1991). B3 (Fv)- PE38KDEL, a single-chain immunotoxin that causes complete regression of a human carcinoma in mice. Proc. Natl. Acad. Sci. USA, 88: 8616-8620.

Da Roch AB, Lopes RM, Schwartsmann G (2001). Natural products in anticancer therapy. Curr. Opin. Cancer, 1: 364-369.

Firenzuoli F, Gori L (2007). Herbal medicine today: clinical and research issues. Evid. Based Complement. Alternat. Med., 4: 37-40.

Gurib-Fakim A (2006). Medicinal plants: traditions of yesterday and drugs tomorrow. Mol. Asp. Med., 27: 1-93.

Li J, Xia Y, Kuter DJ (1999). Interaction of thrombopoietin with the platelet complements receptor in plasma: binding, internalization, stability and pharmacokinetics. Br. J. Haematol., 106: 345-349.

McLellan SA, McLellan DBL, Walsh TS (2003). Anaemia and red blood cell transfusion in the critically ill patient. Blood Rev., 17: 195-208.

Olson H, Betton G, Robinson D, Thomas K, Monro A, Kolaja G, Lilly P, Sanders J, Sipes G, Bracken W, Dorato M, Deun KV, Smith P, Berger B, Heller A (2000). Concordance of toxicity of pharmaceuticals in humans and in animals. Regul. Toxicol. Pharmacol., 32: 56-67.

Quiroga EN, Sampietro AR, Vattuone MA (2001). Screening antifungal activities of selected medicinal plants. J. Ethnopharmacol., 74: 8996.

Rousseaux CG, Schachter H (2003). Regulatory issues concerning the safety, efficacy and quality of herbal remedies. Birth Defects Research. Part B, Develop. Reprod. Toxicol., 68: 505-510.

Saad B, Azaizeh H, Abu-Hijleh G, Said S (2006). Safety of traditional Arab herbal medicine. Evid. Based Complement. Alternat. Med., 3: 433-439.
Sani D, Sanni S, Ngulde SI (2009). Phytochemical and antimicrobial screening of the stem aqueous extract of Anisopus mannii. J. Med Plant Res., 3: 112-115.

Seeff LB (2007). Herbal hepatotoxicity. Clinics Liver Dis., 11: 577-596.

Shin JW, Park HJ, Kwon M, Son CG (2010). Scientific evaluation of the chronic toxicity of the herbal medicine CGX in beagle dogs. Food Chem. Toxicol., 48: 743-749.

Stickel F, Patsenker E, Schuppan D (2005). Herbal hepatotoxicity. J. Hepatol., 43: 901-910.

Sunmonu TO, Oloyede OB (2010). Performance and haematological indices in rats exposed to monocrotophos contamination. Hum. Exp. Toxicol. doi:10.1177/0960327110363441

Tang JL, Liu BY, Ma KW (2008). Traditional Chinese medicine. Lancet, 372: 1938-1940.

Van Wyk BE, van Heerden F, van Oudshoorn B (2002). Poisonous Plants of South Africa. Briza Publications, Pretoria, pp. 66-67.

Wintola OA, Sunmonu TO, Afolayan AJ (2010). The effect of Aloe ferox Mill. in the treatment of loperamide-induced constipation in Wistar rats. BMC Gastroenterol, 10: 95.

Wojcikowski K, Johnson DW, Gobé G (2004). Medicinal herbal extracts - Renal friend or foe? Part one: The toxicities of medicinal herbs. Nephrol., 9: 313-318.

Yakubu MT, Akanji MA, Oladiji AT (2007). Haematological evaluation in male albino rats following chronic administration of aqueous extract of Fadogia agrestis stem. Pharmacog. Mag., 3: 34. 